Canadian Journal of Higher Education Revue canadienne d'enseignement supérieur

Volume 48, No. 1, 2018, pages 60 - 81

\title{
Legitimacy at the "Margins": Promotional Strategies in the Canadian For-Profit College Sector
}

\author{
Roger Pizarro Milian
}

University of Toronto

\begin{abstract}
Conventional scholarship within the sociology of education and organizations posits that schools achieve legitimacy by virtue of conforming to normative standards, abiding by government regulations and mimicking the forms of successful peers. Through this study, an examination of a sample of 751 Canadian for-profit colleges (FPCs) is performed, revealing the presence of an alternative logic. Rather than conformity, organizations within this sector engage in niche-seeking behaviour, using promotional materials to carve out unconventional identities. They do so by directly drawing on symbolic resources and affiliations from the industrial sectors which they service. These findings are interpreted through the prism of contemporary theorizing within organizational sociology.
\end{abstract}

\section{Résumé}

La recherche conventionnelle dans la sociologie de l'éducation et celle des organisations postule que les écoles acquièrent une légitimité en se conformant aux standards normatifs, en suivants les règlements gouvernementaux et en imitant les méthodes de leur pairs réussies. Dans le cadre de cette étude, j'examine le matériel promotionnel d'un prélèvement de 751 collèges canadiens à but non lucratif (FPC: Canadian for-profit colleges) qui fonctionnent selon une méthode divergente. Plutôt de se conformer à un standard fixe, les organisations dans ce secteur s'engagent dans la recherche pour localiser des champs « niche » en utilisant du matériel promotionnel pour démarquer des identités non conventionnelles. Ils le font en s'appuyant sur des ressources symboliques et des affiliations des secteurs industriels qu'ils servent. J'interprète ces résultats à travers le prisme de théorie contemporaine dans le cadre de la sociologie organisationnelle. 


\section{Introduction}

Traditional theorizing within the sociology of education and organizations (e.g., Meyer \& Rowan, 1977, 1978) posits that schools acquire legitimacy via conformity. This entails abiding by established field norms, following government regulations, and emulating the practices of what are considered successful peers (DiMaggio \& Powell, 1983). This logic, part of a broader perspective dubbed the "New Institutionalism" (Selznick, 1996), hypothesizes that the pursuit of legitimacy prompts organizational populations to become progressively "isomorphic" over time, as they strive to develop ideal-typical forms. In post-secondary education (PSE), one of the primary ways in which this plays out is through the emulation of highly selective and research-intensive elites, such as the American "Ivy Leagues" or the British "Oxbridge" (Brint, Riddle, \& Hanneman, 2006; Sauder \& Espeland, 2009). Despite achieving widespread popularity across multiple fields (see Stevens, Armstrong, \& Arum, 2008; Scott, 2010), critics have persuasively argued that traditional New Institutionalism does not adequately explain the behaviour of lower-status actors (Davies \& Pizarro Milian, 2016; Davies \& Quirke, 2007; Han, 1994; Levy, 2004, 2006; Philips \& Zuckerman, 2001, 2013). Within the field of education, such organizations have repeatedly been shown to eschew longstanding field norms, adopting far more specialized, vocationally oriented, and "no frills" forms than their higher-status counterparts (Brint \& Karabel, 1991; Pizarro Milian \& Quirke, 2017).

Despite providing sound criticisms of the New Institutionalist perspective, and more specifically, its logic of isomorphism, few researchers have ventured to analyze the alternative strategies used by low-status educational organizations to achieve legitimacy. Little effort has been devoted to empirically mapping how these marginal actors, known to eschew normative standards and adopt eccentric forms, package and "sell" their services to prospective students accustomed to conventional service providers. To be clear, the term "marginal" is used here not to downplay the contributions of this institutional type to Canadian society, but rather to emphasize their peripheral location within the broader PSE system, including not just (1) their unconventional forms, but also, their (2) tendency to service niche segments of student markets, and to (3) receive limited attention from academics, policy makers, and the public alike. To explore the marketing practices of this organizational population, this study examines the promotional materials produced by 751 Canadian for-profit colleges (FPC). It asks: How does this peculiar institutional type carve a space for itself within a hyper-competitive and centuries-old marketplace? What tactics does it employ to attract educational consumers? The examined data suggest that Canadian FPCs render themselves appealing by emphasizing their (1) connections to industry and (2) linkages to "legitimacy providers" (Bareto \& Baden-Fuller, 2006). In place of mimicking distant elite peers, they legitimate their distinctive forms primarily by engaging in niche-seeking, drawing on symbolic resources from the industrial sectors they service. In doing so, they travel an alternative pathway to legitimacy, one that circumvents taken-for-granted and highly institutionalized ways of organizing within the field of PSE.

\section{A Primer on For-Profit Colleges}

Several factors combine to restrict the current availability of research on FPCs. In the United States, Stevens (2015) notes that researchers tend to gravitate towards the study of more prestigious institutional types, such as selective liberal arts colleges and research- 
intensive universities, despite the fact that FPCs and community colleges are now the "workhorses" of that system, educating an increasing share of its students. ${ }^{1}$ In addition, across Canada, scholars note that FPCs have been ignored historically in government PSE planning, leaving only a small footprint in domestic policy discourse or research (Li \& Jones, 2015; Sweetman, 1993). Combine this skewed scholarly and policymaker attention with the challenge of tracking an organizational population that is in constant flux (Davies \& Taylor, 2007; Martin \& MacLaine, 2016), and it is of little surprise that the amount of existing research on more elite and traditional forms of PSE far outstrips that focusing on FPCs. Despite these circumstances, it is possible to piece together a rudimentary yet useful profile of FPCs using an assortment of American and Canadian sources.

Broadly speaking, North American FPCs are known to be relatively small entities. The average Canadian FPC enrols approximately 150 students annually and employs only a handful of instructors (R.A. Malatest \& Associates, 2007; also see Auld, 2005; Martin \& MacLaine, 2016). Deming, Golding, and Katz (2013) cite similar figures within the American context, yet note that there is great variation across institutions. FPCs in that national sector are said to range from "mom-and-pop operations to giant shareholder-owned chains" (Kinser, 2007, p. 217; also see Kinser \& Levy, 2007, p. 113-116). At the time of writing, however, Canada has yet to witness the emergence of a large chain of FPCs akin to American giants, such as the University of Phoenix. As a whole, though numbering at well over a thousand institutions across Canada (Martin \& MacLaine, 2016), FPCs only educate a small fraction ( $~ 8 \%$ ) of all PSE students (Statistics Canada, 2016). Beyond size, we know that only a small percentage (11\%) of these Canadian FPCs rely on government sources (e.g., second career programs) for a majority of their funding (R.A. Malatest \& Associates, 2007), meaning that they are heavily dependent on student tuition, and thus, directly exposed to market forces (Auld, 2005; Pizarro Milian \& Quirke, 2017).

The market dependency discussed above renders FPCs a relatively volatile population, one that is exposed to routine turnover. It also forces FPCs to embrace more "flexible and responsive" structures in order to remain competitive (Bailey, Badway, \& Gumport, 2001, p. 9; Pizarro Milian \& Hicks, 2014). Perhaps as a result, they are said to better accommodate the needs of mature and non-traditional students, offering expedited and vocationally oriented programming in a variety of fields (e.g., hairstyling, truck driving), as well as flexible class schedules, online forms of delivery, and multiple enrolment entry points (Adamuti-Trache, 2008; Auld, 2005; Toor, 2015). Such flexibility also permeates other organizational functions (Kinser, 2015). As Baldwin, Badway, and Gumport (2001) observed at a FPC they studied, when additional staff were needed, "only one or two staff members are involved in the hiring decision" (p. 28). They described this process as,

more expedient than the typical community college practise of shared governance in hiring decisions, in which a team of instructors and administrators "paper screens" applications, determines which candidates to interview, conducts a group interview process, and then discusses impressions among faculty. (Baldwin, Badway, and Gumport, 2001, p. 28)

These flexible structures give FPCs a competitive advantage vis-à-vis public or nonprofit competitors, making them appealing to non-traditional student groups (Martin \& MacLaine, 2016; Pizarro Milian \& Hicks, 2014; Pizarro Milian \& Quirke, 2017; Toor, 2015). FPC students tend to be older and come from lower-income families (R.A. Malatest 
\& Associates, 2008). Most do not enter PSE directly after high school, citing career indecision and a lack of interest, among other reasons (R.A. Malatest \& Associates, 2008). This tendency contrasts with the traditional North American PSE student, who is often younger, more affluent, and enters PSE directly from high school (Academica Group, 2005; Deil-Amen, 2015). Despite their low-SES background, almost all students at Canadian FPCs graduate, and most tend to be satisfied with their education (HESA, 2012). The majority of Canadian FPC graduates are employed six to nine months after graduation, earning approximately $\$ 26,000$ annually through jobs generally related to their training (R.A. Malatest \& Associates, 2009). However, they tend to lag behind public counterparts on a host of economic outcomes (see Li, 2006; Pizarro Milian \& Hicks, 2014), including income and unemployment rates.

Despite there being plenty of organizational diversity across this sector, its broader social reputation has arguably been tarnished over the last decade by a series of (i) government reports, (ii) high-profile media exposés of deviant FPC administrators, and (iii) sudden school closures. In Ontario, for example, both the Office of the Auditor General of Ontario (2011) and the Ombudsman's Office of Ontario (Marin, 2009) have closely inspected the provincial ministry's handling of the sector, and have identified substantial room for improvement in their oversight of FPCs. Parallel investigations have also been recently carried out in British Columbia (Office of the Ombudsperson, 2015). The news media has also periodically covered the sector. The Toronto Star, in particular, has published pieces based on undercover investigations that have unearthed questionable behaviour by FPC administrators (e.g. Brazao, 2009; Brazao \& Zlomislic, 2009; Zlomislic, 2009). The unexpected bankruptcy of Everest College in 2015 also brought FPCs into the limelight, with multiple stories of students left stranded by the institution receiving considerable media attention (see Harris, 2015; Rushowy, 2015). These Canadian developments have been mirrored by similar events south of the border, including the uncovering of fraudulent recruitment practises and unethical behaviour on the part of some FPC administrators, along with poor graduate outcomes (U.S. Government Accountability Office, 2011; also see McMillan-Cottom, 2017). This negative attention has placed a dark cloud over even reputable FPCs within the sector, augmenting pressures to effectively communicate their value to student markets (Pizarro Milian, 2016).

\section{New Institutionalism and Marketing within PSE}

Early New Institutionalist texts (Meyer \& Rowan, 1977, 1978) tell us that, especially within older fields like PSE, there are strong pressures for organizations to conform to established practices. When faced with uncertainty, decision makers are said to model their structures after "organizations in their field that they perceive to be more legitimate or successful” (DiMaggio \& Powell, 1983, p. 152; also see Haveman, 1993; Bareto \& Baden-Fuller, 2006). Within PSE, scholars have normally interpreted this to mean the mimicking of prestigious, selective, and research-intensive universities (Pizarro Milian, 2016). Acceptance into these elite institutions is coveted by both students in search of credentials offering a labour market premium, and faculty members seeking lighter teaching loads and robust research supports (Trow, 1996). As Scott (2010) notes, "although colleges within the U.S. vary enormously in numerous ways, a predominant pattern is to form a snakelike line with the smaller and less well-endowed schools doggedly attempting to follow the direction set by the more prestigious colleges" (p. 12). This isomorphic logic 
has gained widespread currency within educational research, having been applied successfully as an explanatory narrative for varied organizational processes (Frank \& Meyer, 2007; Meyer, Ramirez, Frank, \& Schofer, 2007; Morphew \& Huisman, 2002).

Isomorphism is also supported by a growing literature on PSE marketing. This body of work finds that promotional materials do little to emphasize institutional distinctiveness, with actors opting instead to showcase highly conventional and esteemed characteristics (Toma, 2009). Clayton, Cavanagh, and Hettche (2012), for example, found that university commercials routinely conveyed images of individuals working within laboratory settings-a tactic used to stress institutional research intensiveness (also see Harris, 2009). PSE organizations have also been found to showcase orthodox physical features. Tobolowsky and Lowery (2014), for example, found that university commercials typically "showed expansive, beautifully manicured, and lush campus grounds, which provided the lure of curb appeal" (p. 85). As Saichaie and Morphew (2014) argue, the degree of consistency in depictions of physical facilities displayed across promotional materials is a "testament to the institutionalized notion of what prestigious colleges and universities look like" (p. 525). More broadly, marketing research has highlighted that universities promise students a "rich life," consisting of a combination of robust academics and an expansive social calendar (Tobolowsky \& Lowery, 2014, pp. 89-90). These are the trends which have been observed in recent empirical work focusing on Canadian universities. Pizarro Milian (2017) found that Canadian universities emulate a highly institutionalized template, portraying themselves as institutions offering academic rigour, lush physical facilities, and a socially vibrant environment. Davidson (2015) has also found an increasing focus within viewbooks on the student experience. In its totality, this literature supports the notion of isomorphism, given that organizations place a premium on signalling conformity with ideal-typical and relatively prestigious forms.

Though achieving great currency, the concept of isomorphism, especially in its mimetic form (Mizruchi \& Fein, 1999), whereby institutions emulate successful peers, has been exposed to repeated refinement. Galaskiewicz and Wasserman (1989), drawing inspiration from network theorizing (e.g., Granovetter, 1973, 1985), argued that ties between organizations could "act as a conduit to disseminate ideas and innovations throughout an organizational field” (p. 456). Their research found that firms emulated organizations to whom they were directly connected, as opposed to more distant field leaders. Han (1994) also argued that organizational prestige structures patterns of mimicry. Rivalries drive elite firms to avoid travelling paths carved out by competitors and to develop relatively distinctive forms, yet mid-status organizations meticulously retrace the steps of successful peers to elevate their own status. At the bottom of the status hierarchy, however, Han (1994) notes there is also limited interest in signalling conformity. This is due, in part, to the cost-prohibitive nature of copying certain forms and actions (e.g., hiring elite personnel, building lucrative facilities).

A number of recent Canadian sociological studies (Aurini, 2006; Davies \& Quirke, 2007; Quirke, 2009, 2013) support these refinements to the New Institutionalism. Quirke's $(2009,2013)$ pioneering work on Toronto private K-12 education has found that lower-status schools typically violate field norms and ignore the actions of elite peers, embracing specialized curriculums, "no-frills" physical facilities, and teacher's lacking formal credentials. In spite of this, low-status schools are able to render themselves appealing by catering to emerging parental preferences for more intensive child-rearing strategies (see 
Quirke, 2006, for an overview). They emphasize their ability to provide personalized attention and a more "nurturing" learning environment (Quirke, 2013; Pizarro Milian \& Quirke, 2017b). This strategy entails branding these low-status private schools as polar opposites to large and highly bureaucratized public competitors.

The singular contemporary study (Pizarro Milian \& Quirke, 2017) that has empirically examined the promotional practices of FPCs in Canada has found parallels with Quirke's (2009, 2013) work. FPCs in Ontario, Canada's most populous province, have been found to engage in niche-seeking behaviour, highlighting both their provision of job-market skills, as well as the convenient location of their campuses. However, this existing work has several obvious limitations. First, it focuses only on a sample of FPCs in one Canadian province. Secondly, it relies exclusively on textual data from online promotional profiles, and as such, neglects the attention given to graphical material in recent PSE research (Drori, Delmestri, \& Oberg, 2015; Metcalfe, 2010, 2012, 2015). This study aims to overcome these limitations by examining vast amounts of textual and graphical data contained on the home pages of a sample of FPCs dispersed across Canada. It employs this more robust approach to produce an enhanced understanding of how FPCs render themselves legitimate in the eyes of consumers, despite adopting unconventional characteristics and eschewing field norms.

\section{Data and Methods}

I began by using data scraping software to automatically "crawl" and extract website addresses from all 1,308 FPC $^{2}$ profiles listed on the Canadian Information Centre for International Credentials (CICIC) directory at the time of writing. CICIC, a subunit of the Council of Ministers of Education, Canada (CMEC), was established in 1990 to provide information to organizations (e.g., employers, schools) on the standing of Canadian academic institutions and their credentials. It is an authoritative entity within Canadian PSE, and the only one that publicizes a comprehensive list of registered domestic FPCs. A total of only 1,179 links were extracted from crawled profiles, given that some represented institutions without a website at the time of writing. Addresses were compiled into a spreadsheet and subsequently screened manually and using Excel functions. At times, profiles belonging to franchises or branch campuses of a broader entity provided links to the same "master" website. Eliminating such duplicates produced a sample of 914 unique addresses. This constitutes the entire population of registered Canadian FPCs with websites at the time of sampling. It is the collective online "face" of the sector.

I proceeded by using RapidMiner Studio, a data scraping and analytics software package, to extract the textual content of each FPC home page. However, it was not possible to gather textual data from all home pages. First, 39 (4.3\%) of all unique FPC links led to pages that were not active or currently under construction (e.g., "down"). These pages contained no relevant content and were thus excluded. Second, 124 (13.6\%) sites used media formats (e.g., Flash), or preventative scripts, that rendered text within them unreadable to the scraper software. Despite these occurrences, the outlined procedures generated a large textual data set, representing 751 Canadian FPCs (82.2\% of unique links), composed of 362,267 words-the equivalent of 573 single-spaced pages of text.

Web pages have been employed as a unit of analysis in numerous existing studies of online educational marketing (Drew, 2013; Gordon \& Berhow, 2009; Pizarro Milian \& David- 
son, 2016; Pizarro Milian \& McLaughlin, 2016; Will \& Callison, 2006), lending legitimacy to their usage here. Observers note that within the contemporary PSE landscape, effective online advertising is critical (Belanger et al., 2014; Kimmons, Veletsianos \& Woodward., 2017). Websites have been depicted as mediums through which organizations project an appealing identity (Pizarro Milian, 2017b; Powell et al., 2016), and through which prospective customers are enticed to take a "closer look" (Winter, Saunders \& Hart, 2003, p. 311). The studied home pages serve as virtual gateways, and thus, captivate relatively more attention than those (e.g. department or program sites) that are situated multiple "clicks" into an institutional webpage. This assumption is supported by research that depicts web searching as an economical process, with individuals often satisfying their information needs in mere moments (Hölscher \& Strube, 2000; Jansen, Spink, \& Saracevic, 2000). By virtue of serving as these primary "gateways" for visitors, home pages are of vital interest for administrators desiring to communicate a favourable organizational image.

Gathered home page content was subjected to a mixed-methodological form of content analysis that strove to provide a basic, objective and quantitative description of webpage content, ${ }^{3}$ alongside a more nuanced qualitative interpretation of their "symbolic" content (Krippendorff, 2012; Metcalfe, 2015). As such, this multifaceted strategy aimed to systematically categorize elements of the studied web pages, while also assembling a broader understanding of their meaning. RapidMiner Studio was used to calculate the number of times each word or bigram (two-word combination) appeared across all home pages, as well as the number of unique websites in which they appeared. This initial step was not designed to generate stand-alone findings, but to provide an expedient and informative overview view of textual trends. As Stemler (2001) notes, word frequencies are a widely accepted form of quantitative content analysis. This method, however, is susceptible to underestimating specific terms' qualitative significance. For example, counts are not sensitive to the color or size of textual passages, and as such, potential emphases intended by content designers. Counts are also insensitive to synonyms and words with more than one meaning.

This initial quantitative analysis was complemented with a qualitative inspection of home pages. The home pages of 180 random FPCs (24\% of total) were visited, and screenshots of them were captured using an extension for the Google Chrome browser. Screenshots were then imported into the QSR NVivo package for manual coding. To analyse home page screenshots, a two-pronged approach, with both inductive and deductive elements (see Quirke, 2016, for an application), was employed. The author simultaneously explored how popular word clusters flagged through quantitative analysis were used, while remaining open to emergent themes across web pages. The latter is common practice across studies performing inductive qualitative content analysis (Kondracki, Wellman, \& Amundson, 2002). Content analysis of this sort assumes that text and other symbols represent broader social structures, and can reveal the traits of their producers (Krippendorff, 2012). As Davidson (2015) argues, this approach has proven useful for producing valuable insights within the PSE marketing literature (p. 201). The number of manually coded screenshots (180) reflects the point of "saturation" (Glaser \& Strauss, 2017; Suddaby, 2006), at which the author felt confident that they possessed a thorough understanding of trends within the data. That being said, the patterns presented in this paper were clearly noticeable after having coded approximately 80 screenshots. 


\section{Findings}

Below, quantitative trends in the textual content of home pages are covered. The attention then shifts towards observations made through the more in-depth, qualitative inspection of home pages. This allows for a transition from the general to the specific, from broader trends to richer contextualization.

\section{Exploratory Quantitative Analysis}

An analysis of word and bigram counts allowed me to identify six distinct clusters of terms with similar meaning, and likely associated with promotional strategies used by FPCs (see Table 1). The first was a group of flattering descriptors, such as "great," "good," and "exciting." These are descriptors that could easily be applied by FPCs in a self-aggrandizing manner, to instructors or programs, in order to portray them in a positive light. Their presence across FPC home pages is contrasted by the general absence of descriptors used informally across status-conscious academic circles (Hermanowicz, 2005), such as "prestigious" or "elite," which appeared in less than $3 \%$ of all examined FPC home pages. Beyond such self-congratulatory language, there were references to what appeared to be particular types of knowledge, such as "applied," "practical," and "hands-on." These are terms that existing work (Pizarro Milian \& Quirke, 2016) has found FPCs use to emphasize their provision of more specialized and vocational forms of training, as opposed to more liberal forms of education. There was also a cluster of words across home pages that was seemingly associated with labour markets, including "industry," "jobs," and "work." These are terms that existing research has also found FPCs employ to highlight how the training they provide is synchronized with the needs of employers. Again, there is a contrast between more liberal curriculums and less practical types of training, which have historically been offered through conventional PSE organizations (Brint, Riddle, Turk-Bicakci, \& Levy, 2005). In the latter, students are exposed to a range of ideas that often have little bearing on tasks performed in future occupational roles.

Beyond the above-mentioned themes, two additional word clusters also seemingly showcased the relationship FPCs shared with (i) geographical regions and (ii) legitimate external entities. In the former, this consisted of references to a city (e.g., "Toronto") or province ("British Columbia"). In previous work, the referencing of regions has been found to go in hand with discourses of convenience, with FPCs flaunting their closeness to urban centres and public transportation (Pizarro Milian \& Quirke, 2017). Among Canadian community colleges, a discussion of regions on promotional materials has also been associated with more social justice-related themes, through which institutions portray themselves as catering to under-represented student groups within their communities (Pizarro Milian, 2016a). A plethora of references across web pages to "accreditation," "associations," and "registrations" also hinted at the conjuring of legitimacy providers (Barreto \& BadenFuller, 2006; Deephouse, 1996). These are the entities that possess an accepted mandate, either from government or their membership, to certify the quality of actors within the sector. As existing work (Baum \& Oliver, 1991) within the field of organization studies notes, linkages to these actors provide a boost to the perceived legitimacy of organizations and increase their chances of survival. Lastly, a cluster of words that referred to temporal units was identified, ranging from hours to weeks to years. The meaning of this last word cluster, however, was not possible to ascertain through the quantitative analysis. 


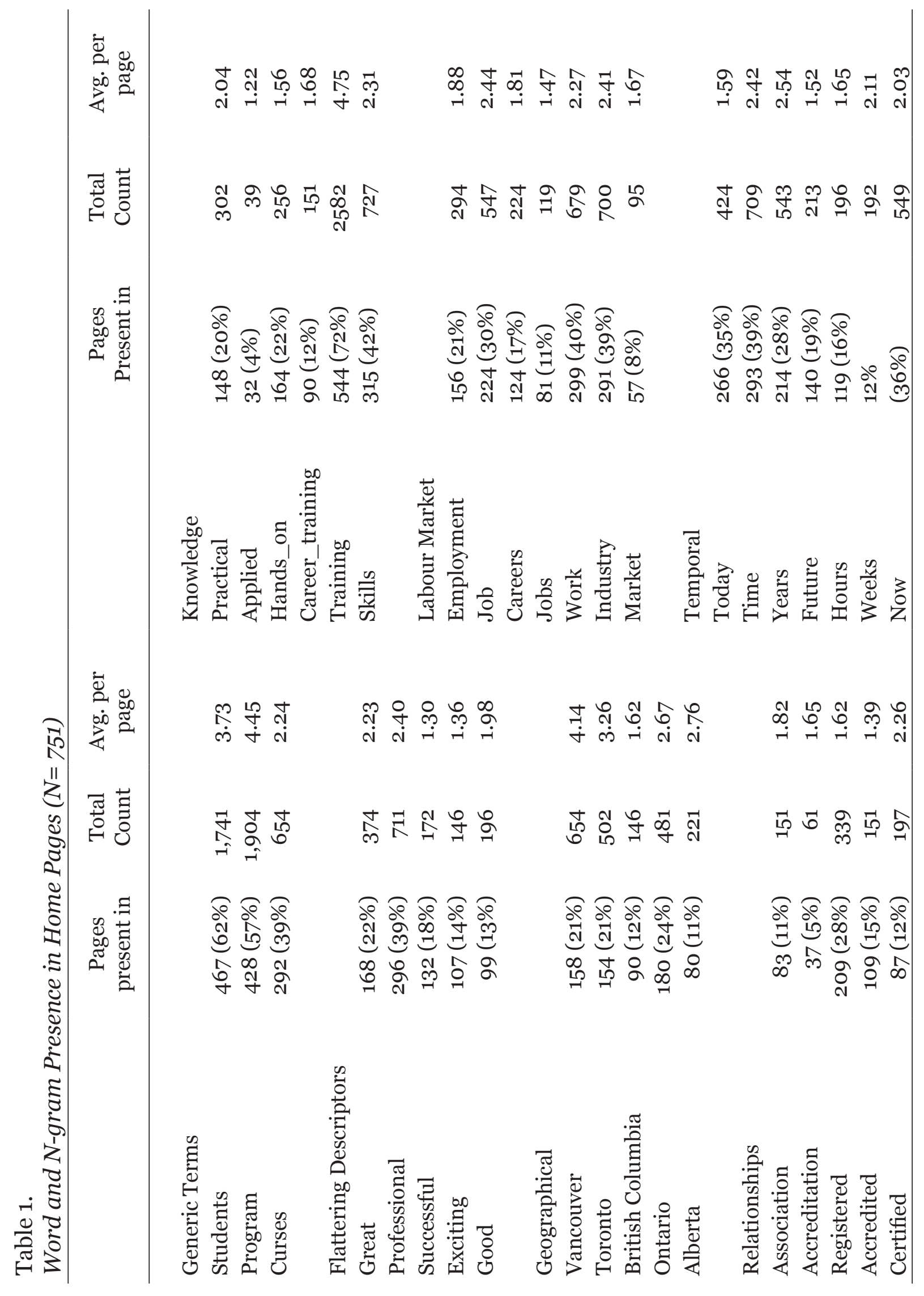




\section{Qualitative Analysis}

A qualitative inspection of FPC home pages allowed for the formulation of a more comprehensive and nuanced understanding of promotional practices. On numerous occasions, images were used on FPC home pages to emphasize organizational features that were also referenced textually. A more in-depth analysis of websites also allowed for the identification of novel marketing tactics that went undetected through quantitative textual analysis. The latter, in particular, lends credence to the adoption of a mixed-methodological approach. Below, the findings of the qualitative inspection are presented through a discussion of typical examples from home pages.

Industry Symbols. An immediately noticeable characteristic of FPC websites was the extent to which they drew on symbols from connected industrial sectors, those which they serviced through their educational programs. This was, by far, the most common trend identified through manual coding, appearing 298 times across $77.8 \%$ (140/180) of examined home pages. This strategy was executed in two distinct ways. The first entailed placing images of physical objects sharing an explicit correspondence with a trade or professional industry. For example, FPCs specializing in truck driver training or heavy equipment operation would prominently display pictures of transport trucks or excavators on their websites. These symbols where displayed both on location, in this case, highways or construction sites, as well as incorporated into institutional logos. A second way in which industry symbols were displayed on FPC home pages was through the usage of images depicting individuals performing occupational tasks with "tools of the trade." FPCs specializing in the beauty industry, for example, prominently displayed pictures of hairstylists cutting hair with scissors or applying colour, make-up artists applying mascara with brushes, and aestheticians providing skin treatments with creams or nail technicians giving pedicures with nail files. Those providing training in health care professions displayed individuals wearing "scrubs" and measuring elderly patients' heart pressure, or carefully supporting them as they walked down corridors at nursing homes. FPCs providing business programs also prominently displayed pictures of individuals dressed in formal business attire, sitting around conference tables, and watching co-workers give presentations. Through such images, FPCs provided a window into the occupational futures for which they prepared students. In doing so, they provided highly specialized images that, though similar in structure, employed entirely different sets of symbolic resources.

It is important to contextualize the usage of these symbols in reference to branding strategies observed across other PSE sectors. Recall that, as mentioned earlier, university marketing is typically guided by efforts to signal conformity with institutionalized templates (Pizarro Milian, 2017; Toma, 2009). When it comes to institutional logos, for example, this typically entails flashing antiquity or tradition through coats of arms with religious or mythical elements (e.g., a Bible, the Phoenix) and Latin phrases (Baruch, 2006; Holloway \& Holloway, 2005; Pizarro Milian, 2016). Other symbols, representing science or national culture, are also at times incorporated into logos to communicate legitimate identities to external stakeholders (Drori, Delmestri, \& Oberg, 2015, pp. 170-176). Even Canadian community colleges, which also specialize in occupationally-oriented training, fail to align their institutional logos with a single industry. Though eschewing traditional imagery (e.g., coats of arms), they are found to embrace corporate-like branding styles 
that render them as modern, but also highly generic (Pizarro Milian, 2016a; Pizarro Milian \& Davidson, 2016). Relative to such strategies, the incorporation of mundane industry-specific symbols and occupational activities into the promotional materials of FPCs certainly sets them apart from their peers across PSE. These trends are interpreted as evidence suggestive of niche-seeking behaviour, as opposed to isomorphism, among the FPC population. FPCs were observed through this study constructing specialized brand identities which bear little resemblance to those of peers outside of their immediate market.

These visual representations of particular industries and occupations appeared alongside textual passages containing words previously identified through quantitative analysis as belonging to the types of knowledge and labour markets clusters. A qualitative inspection of such passages revealed that a sizable group of FPCs $(58 / 180$ or $32.2 \%)$ attempted to depict themselves as being synchronized with industry needs. The RAYWAY Operator Training School Ltd., for example, claimed to have "regular contact with mine recruiting companies, developers, builders, and local contractors," entities whose need for "well-trained, safety conscious operators with a great attitude" the school proclaimed to understand. Such awareness of employer needs was depicted as allowing FPCs to develop programs that could provide the in-demand, industry-specific, and, more specifically, "hands-on" training (39/180 or $21.7 \%$ ) required for successful labour market transitions. CDI College similarly claimed that its programs were designed to provide students with useful "practical, hands-on learning experiences." It purported to offer "solid market-driven programs" that helped students "develop the skills that are most in-demand by employers." These discussions of synchronicity between FPC structures and industry were at times embedded across home pages within depictions of labour markets that took a decidedly alarmist tone, describing them as ever-changing, fiercely competitive, and requiring cutting-edge skills. The promotional "hook" seemingly being that FPCs possessed programming that would prepare students to excel within this harsh environment. This promotional strategy highlighted above also ostensibly capitalizes on broader discourses about the supposed mismatches between traditional university programs, in disciplines like anthropology, English literature, and sociology, and the needs of industry (Munro, McLaine, \& Stuckey, 2014; Stuckey \& Munro, 2013). These programs are often characterized by critics as inward-facing relics, run by academics having little understanding of the needs of employers, and the skillsets which will get students hired upon graduation. FPCs brand themselves as stark alternatives, as industry-oriented entities that can serve as smooth pathways to employment.

Institutional Linkages. The second most popular theme found across FPC websites through qualitative analysis, occurring 149 times across 60\% (108/180) of home pages, consisted of signalling relationships with legitimate external actors, or "legitimacy providers," as they have been termed within the organizational literature (Barreto \& BadenFuller, 2006; Deephouse, 1996). These entities are depicted as "legitimate" given that they have been granted charters, either through legislation or their voluntary memberships, to oversee, certify, or represent FPCs. Referenced actors fell within three main categories: (1) sector-specific advocacy groups (e.g., Career Colleges Ontario), (2) program-specific accreditors or associations (e.g., Professional Truck Driving Institute), or (3) government entities with which FPCs were registered (e.g., Ontario Ministry of Training, Colleges and Universities). At times, references to affiliations with these entities consisted of the simple 
placement of their logo, lacking any accompanying text. This gives the impression that their meaning is well-understood within the sector, and thus taken for granted by field members. When ties to these actors were explained, however, the explanations often drew upon terms listed under the relationship word cluster. This was done in a manner eerily similar to how educational credentials are listed on an individual's curriculum vitae. References to external entities were often provided in a list-like fashion, presented as credentials or "badges" attesting to the institution's credibility. This flashing of affiliations is a promotional tactic that has not been observed across recent empirical studies of other sectors of Canadian PSE, including universities and public colleges (Pizarro Milian, 2016a, 2017; Belanger et al., 2014; Davidson, 2015). This may be due to the fact that larger and older organizations within the field of PSE have more established reputations. This may render it unnecessary or ineffective, for example, for an institution like the University of British Columbia or McGill University to attempt to signal legitimacy by referencing their legal standing.

\section{Discussion}

Navigating across Canadian FPC home pages does not give the impression that one is observing a single organizational population. In fact, the collective "face" of the sector is highly fragmented. This is essentially the case because industry symbols and institutional linkages vary widely across program areas. An FPC specializing in beauty-related programming (e.g., hair styling, aesthetics) will present itself in an entirely different manner than one focusing on heavy equipment operation. The bearded male construction workers, excavators, and industry associations showcased by the latter will bear little resemblance to the fashionable female hairstylists, beauty salons, and industry links advertised by the former. These fault lines in the symbolic landscape of the sector produce great variation in the ways in which FPCs attempt to legitimate themselves in the eyes of educational consumers. This strongly contrasts dynamics within the Canadian university sector, where institutions are found to conform to highly institutionalized templates (Pizarro Milian, 2017). The observed behaviour within the FPC sector is difficult to reconcile with conventional wisdom within the New Institutionalism. Neither the mimicry of high-status forms, strong normative standards, nor government regulations appear to be behind the adoption of these promotional tactics. Instead, the Canadian FPC sector appears to be characterized by a unique form of niche-seeking, one which leads to the balkanization of the sector's public face. This niche-seeking behaviour is infused with symbolic resources produced in connected industrial sectors by actors that are not themselves engaged in providing educational services. In addition, it is embedded within broader discourses of occupational training (e.g., hands-on skills) that have failed to achieve hegemonic status in other sectors of the Canadian PSE system. (Pizarro Milian, 2016a).

These empirical findings are consistent with contemporary refinements to the New Institutionalist perspective. Canadian FPCs' innovative marketing strategies are in accord with Han's (1994) suggestion that low-status organizations will be less concerned with signalling conformity with field norms. Their proclivity to draw on symbolic resources from connected industrial sectors, those which they service through their programming and claim to have connections with, is also consistent with Galaskiewicz and Wasserman's (1989) argument about the importance of network ties in the diffusion of organizational practices. Lastly, like Davies and Quirke's (2007) private K-12 schools, we see that Canadi- 
an FPCs also appear to tap into niche markets that are defined largely in opposition to field norms and the traits of elite peers. Canadian FPCs are carving out a space for themselves within a crowded marketplace as providers of industry-specific and hands-on training, an image which is the ideological antithesis of the liberal arts model espoused by most North American universities (Kraatz \& Zajac, 1996). Such contrast is clearly visible in the way in which this institutional type sells itself through online promotional materials.

Despite having documented these trends, much work is still left to be done in order for researchers to more holistically understand promotional behaviour within the Canadian FPC sector. In particular, attention needs to be paid to the micro-processes that lead to the enactment of these documented strategies. How do FPC administrators rationalize their decision to project these sorts of organizational identities through their promotional materials? Do observed trends constitute a form of strategic positioning, through which administrators attempt to avoid head-on competition with more established peers (Brint \& Karabel, 1991; Fumasoli \& Lepori, 2011; Fumasoli \& Huisman, 2013)? Or, is the conjuring of these industry symbols, and execution of these broader promotional strategies, perhaps rooted in more ritualistic behaviour (Meyer \& Rowan, 1977)? Is an appreciation of these symbols injected into FPCs through the hiring and employment of individuals from these connected industrial sectors (e.g., hairstylists, truck drivers)? Qualitative research on these issues is certainly needed and would be in line with a broader movement within the New Institutionalist perspective to empirically map the micro-level foundations of organizational behaviour (Powell \& Colyvas, 2008; Powell \& Rerup, 2017). Such work, of course, is beyond the scope of this current analysis.

\section{Conclusion}

This study makes several contributions to the extant literature. Empirically, it is the first national-level study of marketing practices in the Canadian FPC sector. It examines a larger sample of FPCs, and four times as much textual data, as the only existing study on the subject. It also analyzes patterns in the visual content of promotional materials left unexamined in previous work. Such characteristics allow for the production of a far more holistic understanding of the stratagems that FPCs employ to render themselves attractive to students, and thus, carve a niche for themselves within a centuries-old marketplace. Theoretically, this study also provides support for refinements made to the New Institutionalist perspective over the years. It points to a PSE sector within which the traditional isomorphic logic of the New Institutionalism does not extend, and by doing so, provides a corrective to the ceremonial conjuration of this logic in PSE research. Methodologically, this study employs a mixture of manual and computer-assisted data gathering methods seldom used by scholars of education to create two novel data sets. It exposes such empirical evidence to a unique blend of quantitative and qualitative content analysis that allows for the charting of vast amounts of promotional material. This specified methodological approach provides a template that future researchers can adopt to effectively map promotional behaviour across additional PSE sectors.

As always, caution should be exercised when interpreting the presented findings. Further research is certainly needed to ameliorate limitations of this study. For starters, additional types of promotional materials, such as brochures, billboards, and television commercials, need to be analyzed in order to develop a more complete overview of how 
Canadian FPCs market their services. As evidenced by the novel trends identified through this study that were not captured by earlier work on FPC promotional profiles, certain marketing practices may be tied to particular forms of communication. Alternative media formats employed by FPCs for the purposes of recruitment may exhibit trends that have thus far been undetected through this and earlier studies. The same is true of pages located multiple "clicks" into an institution's website. Further research needs to be done to ascertain if there is any degree of consistency across these promotional materials. Despite these limitations, this study constitutes a first step toward better understanding the promotion of the FPC sector.

\section{Notes}

1. Kirby (2012, pp. 44) relays a similar lack of recent interest in FPCs within Canada, despite evidence suggesting that the sector has expanded in recent years.

2. The categorization of "for-profit" used by CICIC, which relies on administrative data gathered from provincial ministries (CICIC, personal communication), is relied on in this study. Within the context of Canadian PSE, for-profit status denotes that these institutions do not receive direct operating funds from provincial or federal governments, as public universities and colleges do. However, some approved FPCs are able to indirectly access government funds in certain provinces given that students are able to apply for student loans (e.g., OSAP) to pay for tuition.

3. Berelson (1952) provides the classical description of this approach, but see Riff, Lacy \& Fico (2014) and Sink \& Mastro (2017) for contemporary applications.

\section{Acknowledgements}

The author would like to thank the creators of RapidMiner Studio for making this powerful tool available free of charge to academics. He would also like to thank the anonymous reviewers for their constructive feedback on earlier versions of this paper.

\section{References}

Academica Group. (2005). 2005 University Applicant Survey. London, ON. Retrieved from http://odesi2.scholarsportal.info/documentation/CMSF/OUAS/cmsf_ ouas_2005_report.pdf

Adamuti-Trache, M., \& Sweet, R. (2008). Vocational training choices of women: public and private colleges. Gender \& Education, 2O(2), 167-182. http://doi. org/10.1080/09540250701805789

Auld, D. (2005). Selling Postsecondary Education: The Role of Private Vocational and Career Colleges. Toronto: C.D. Howe Institute.

Aurini, J. (2006). Crafting legitimation projects: An institutional analysis of private education businesses. Sociological Forum, 21(1), 83-111.

Bailey, T., Badway, N., \& Gumport, P. J. (2001). For-Profit Higher Education and Community Colleges. Stanford, CA: National Center for Postsecondary Improvement.

Barreto, I., \& Baden-Fuller, C. (2006). To conform or to perform? Mimetic behaviour, legitimacy-based groups and performance consequences. Journal of Management Studies, 43(7), 1559-1581. http://doi.org/10.1111/j.1467-6486.2006.00620.x 
Baruch, Y. (2006). On logos, business cards: the case of UK universities. In A. Rafaeli \& M. Pratt (Eds.), Artifacts and Organizations: Beyond Mere Symbolism (pp. 181-198). London, UK: Lawrence Erlbaum Associates.

Belanger, C., Bali, S., \& Longden, B. (2014). How Canadian universities use social media to brand themselves. Tertiary Education and Management, 2O(1), 14-29.

Berelson, B. (1952). Content analysis in communication research. New York, NY: Free Press.

Brazao, D. (2016). Entrepreneur a jack of all trades, qualified in none. Retrieved December 8, 2016, from https://www.thestar.com/news/investigations/2009/09/17/ entrepreneur_a_jack_of_all_trades_qualified_in_none.html

Brazao, D., \& Zlomislic, D. (2009). Students find career college locked following Star exposé. Retrieved December 8, 2016, from https://www.thestar.com/news/ gta/2009/o9/18/students_find_career_college_locked_following_star_exposeacute.html

Brint, S., \& Karabel, J. (1991). The Diverted Dream: Community colleges and the promise of educational opportunity in America, 1900-1985. New York, NY: Oxford University Press.

Brint, S., Riddle, M., \& Hanneman, R. (2006). Reference Sets, Identities, and Aspirations in a Complex Organizational Field: The Case of American Four-Year Colleges and Universities. Sociology of Education, 79(3), 229-252. http://doi. org/10.1177/003804070607900303

Brint, S., Riddle, M., Turk-Bicakci, L., \& Levy, C. S. (2005). From the liberal to the practical arts in American colleges and universities: Organizational analysis and curricular change. The Journal of Higher Education, 76(2), 151-180. http://doi.org/10.1353/ jhe.2005.0011

Clayton, M. J., Cavanagh, K. V., \& Hettche, M. (2012). Institutional branding: a content analysis of public service announcements from American universities. Journal of Marketing for Higher Education, 22(2), 182-205. http://doi.org/10.1080/08841241 .2012 .737869

David John Frank; Suk-Ying Wong; John W. Meyer; Francisco O. Ramirez. (2000). What Counts as History: A Cross-National and Longitudinal Study of University Curricula. Comparative Education Review, 44(1), 29-53. http://doi.org/10.1086/447590

Davidson, C. (2015). The University Corporatization Shift: A Longitudinal Analysis of University Admission Handbooks, 1980 to 2010. Canadian Journal of Higher Education, 45(2), 193-213.

Davies, S., \& Pizarro Milian, R. (2016). Maintaining Status in Times of Change: The Interplay of Institutional Forces and Stratification among Anglo-American Universities. In J. E. Côté \& A. Furlong (Eds.), The Handbook of Sociology of Higher Education. New York, NY: Routledge.

Davies, S., \& Quirke, L. (2007). The Impact of Sector on School Organizations: Institutional and Market Logics. Sociology of Education, 8o(1), 66-89. http://doi. org/10.1177/003804070708000104 
Davies, S., \& Taylor, O. A. (2006). A Profile of Private Post Secondary Providers in Canada. Ottawa, ON: Canadian Council on Learning.

Deephouse, D. L. (1996). Does isomorphism legitimate? Academy of Management Journal, 39(4), 1024-1039. http://doi.org/10.2307/256722

Deil-Amen, R. (2015). The Traditional College Student: A Smaller and Smaller Minority and Its Implications for Diversity and Access Institutions. In M. Kirst \& M. L. Stevens (Eds.), Remaking College: The Changing Ecology of Higher Education (pp. 134-168). Stanford, CA: Stanford University Press.

Deming, D., Goldin, C., \& Katz, L. (2013). For-profit colleges. Future of Children, 23(1), 137-163. http://doi.org/10.1353/foc.2013.0005

DiMaggio, P. J., \& Powell, W. (1983). The iron cage revisited: institutional isomorphism and collective rationality in organizational fields. American Sociological Review, 2(48), 147-160. http://doi.org/10.2307/2095101

Drew, C. (2013). Elitism for sale: Promoting the elite school online in the competitive educational marketplace. Australian Journal of Education, 57(2), 174-184.

Drori, G., Delmestri, G., \& Oberg, A. (2015). The iconography of universities as institutional narratives. Higher Education, 71(2), 163-180.

Frank, D. J., \& Meyer, J. W. (2007). University expansion and the knowledge society. Theory and Society, 36(4), 287-311. http://doi.org/10.1007/s11186-007-9035-z

Fumasoli, T., \& Huisman, J. (2013). Strategic Agency and System Diversity: Conceptualizing Institutional Positioning in Higher Education. Minerva, 51(2), 155-169. http://doi.org/10.1007/s11024-013-9225-y

Fumasoli, T., \& Lepori, B. (2011). Patterns of strategies in Swiss higher education institutions. Higher Education, 61(2), 157-178. http://doi.org/10.1007/s10734-0109330-X

Galaskiewicz, J., \& Wasserman, S. (1989). Mimetic Processes within an Field : Interorganizational An Empirical Test Stanley Wasserman. Administrative Science Quarterly, 34(3), 454-479.

Glaser, B., \& Strauss, A. (2017). The Discovery of Grounded Theory: Strategies for Qualitative Research.

Gordon, J., \& Berhow, S. (2009). University websites and dialogic features for building relationships with potential students. Public Relations Review, 35, 150-152. http://doi. org/10.1016/j.pubrev.2008.11.003

Granovetter, M. (1973). The Strength of Weak Ties. American Journal of Sociology, 78(6), 1360-1380.

Granovetter, M. (1985). Economic Action and Social Structure: The Problem of Embeddedness Mark Granovetter. American Journal of Sociology, 91(3), 481-510.

Han, S.-K. (1994). Mimetic Isomorphism and Its Effect on the Audit Services Market. Social Forces, 73(2), 637-664. http://doi.org/10.2307/2579824 
Harris, M. S. (2009). Message in a Bottle: University Advertising During Bowl Games. Innovative Higher Education, 33(5), 285-296. http://doi.org/10.1007/s10755-0089085-9

Harris, S. (2015). Everest College grads want loan forgiveness for "worthless" diploma. Retrieved December 8, 2016, from http://www.cbc.ca/news/business/everest-collegegrads-want-loan-forgiveness-for-worthless-diploma-1.3036143

Haveman, H. a. (1993). Follow the Leader: Mimetic Isomorphism and Entry Into New Markets. Administrative Science Quarterly, 38(4), 593-627. http://doi. org/10.2307/2393338

Hermanowicz, J. C. (2005). Classifying Universities and Their Departments : A Social World Perspective. The Journal of Higher Education, 76(1), 26-55. http://doi. org/10.1353/jhe.2005.0005

Holloway, D. A., \& Holloway, D. (2005). University logos and the commoditisation of higher education. In Australian and New Zealand Marketing Academy of Management Conference (pp. 34-40). Retrieved from http://researchrepository.murdoch.edu. au/7950/1/University_logos.pdf

Hölscher, C., \& Strube, G. (2000). Web search behavior of internet experts and newbies. Computer Networks, 33(1), 337-346. http://doi.org/10.1016/S1389-1286(oo)ooo31-1

Jansen, B. J., Spink, A., \& Saracevic, T. (2000). Real life, real users, and real needs: A study and analysis of user queries on the Web. Information Processing and Management, 36(2), 207-227. http://doi.org/10.1016/So306-4573(99)ooo56-4

Kimmons, R., Veletsianos, G. \& Woodward, S. (2017). Institutional uses of Twitter in US higher education. Innovative Higher Education 42(2), 97-111.

Kinser, K. (2007). Dimensions of Corporate Ownership in For-Profit Higher Education. The Review of Higher Education, 30(3), 217-245. http://doi.org/10.1353/rhe.2007.0009

Kinser, K. (2015). Working at a for-profit: The University of Phoenix. International Higher Education, 28, 13-14.

Kinser, K., \& Levy, D. C. (2007). For-profit higher education: US tendencies, international echoes. In J. Forest \& P. Altbach (Eds.), International Handbook of Higher Education (pp. 107-119). Springer International.

Kirby, D. (2012). Marketizing Canadian Higher Education: An Examination of Recent Access Policy Reforms. In State and Market in Higher Education Reforms (pp. 43-55). http://doi.org/10.1007/978-94-6091-800-1_4

Kondracki, N. L., Wellman, N. S., \& Amundson, D. R. (2002). Content Analysis: Review of Methods and Their Applications in Nutrition Education. Journal of Nutrition Education and Behavior, 34(4), 224-230. http://doi.org/10.1016/S1499-4046(o6)60o97-3

Kraatz, M. S., \&Zajac, E. J. (1996). Exploring the Limits of the New Institutionalism: The Causes and Consequences of Illegitimate Organizational Change. American Sociological Review, 61(5), 812-836. http://doi.org/10.2307/2096455

Krippendorff, K. (2012). Content Analysis: An Introduction to Its Methodology. Content Analysis: An Introduction to Its Methodology (Third). Thousand Oaks, California: Sage Publications Ltd. http://doi.org/10.1007/s13398-014-0173-7.2 
Levy, D. C. (2004). The New Institutionalism: Mismatches with Private Higher Education's Global Growth. Albany, NY. Retrieved from http://www.prophe.org/ attachment. $\operatorname{aspx}$ ?id=59

Levy, D. C. (2006). How private higher education's growth challenges the new institutionalism. In H.-D. Meyer \& B. Rowan (Eds.), The New Institutionalism in Education (pp. 143-162). New York, NY: State University of New York Press.

Li, D. (2006). Canada's Private Colleges: The Lesser Known Players in Postsecondary Education. Ottawa, ON. Retrieved from http://www.statcan.gc.ca/pub/11-621-m/11-621m2006036-eng.htm

Li, S., \& Jones, G. (2015). The "Invisible" Sector: Private Higher Education in Canada. In K. Joshi \& S. Paivandi (Eds.), Private Higher Education: A Global Perspective (pp. 1-33). Delhi, India: B.R. Publishing.

Marin, A. (2009). Too Cool for School: Investigation into the Ministry of Training, Colleges and Universities' Oversight of Bestech Academy Inc. and Enforcement of the Private Career College Act. Toronto, ON. Retrieved from https://www.ombudsman. on.ca/Ombudsman/files/82/827917e6-coa2-4ef4-9129-9d1f15f3250o.pdf

Martin, E., \& MacLaine, C. (2016). The Role and Value of Private Career Colleges in Canada. Ottawa, ON: Conference Board of Canada.

McMillan-Cottom, T. (2017) Lower ed: The troubling rise of for-profit colleges in the new economy. New York and London: The New Press.

Metcalfe, A. (2015). Visual Methods in Higher Education. In F. Stage \& K. Manning (Eds.), Research in the College Context: Approaches and Methods (2nd ed., pp. 111-127). New York, NY: Routledge.

Metcalfe, A. S. (2010). Revisiting Academic Capitalism in Canada: No Longer the Exception. The Journal of Higher Education, 81(4), 489-514. http://doi.org/10.1353/ jhe.0.0098

Metcalfe, A. S. (2012). Imag (in) ing the university: Visual sociology and higher education. The Review of Higher Education, 35(4), 517-534.

Meyer, J. W., Ramirez, F. O., Frank, D. J., \& Schofer, E. (2007). Higher Education as an Institution. In P. J. Gumport (Ed.), Sociology of Higher Education: Contributions and their Contexts (pp. 187-221). Baltimore, MD: John Hopkins University Press.

Meyer, J. W., \& Rowan, B. (1977). Institutionalized Organizations: Formal Structure as Myth and Ceremony. American Journal of Sociology, 83(2), 340. http://doi. org/10.1086/226550

Meyer, J. W., \& Rowan, B. (1978). The Structure of Educational Organizations. In M. W. Meyer (Ed.), Environments and Organizations (pp. 78-109). San Francisco, CA: Jossey-Bass.

Mizruchi, M. S., \& Fein, L. C. (1999). The Social Construction of Organizational Knowledge: A Study of the Uses of Coercive, Mimetic, and Normative Isomorphism. Administrative Science Quarterly, 44(4), 653-683. http://doi.org/10.2307/2667051 
Morphew, C., \& Huisman, J. (2002). Using institutional theory to reframe research on academic drift. Higher Education in Europe, 27(4), 492-506. http://doi. org/10.1080/0379772022000071977

Munro, D., MacLaine, C., \& Stuckey, J. (2014). Skills: where are we today?: the state of skills and PSE in Canada. Ottawa, ON: Conference Board of Canada.

Newman, F., Couturier, L., \& Scurry, J. (2010). The Future of higher education: Rhetoric, reality, and the risk of the market. San Francisco, CA: Jossey-Bass.

Office of the Auditor General of Ontario. (2011). Annual Report. Toronto, ON. Retrieved from http://www.auditor.on.ca/en/reports_en/en11/312en11.pdf

Office of the Ombudsperson of British Columbia. (2015). In the Public Interest: Protecting Students Through Effective Oversight of Private Career Training Institutions. Retrieved from https://www.bcombudsperson.ca/sites/default/files/In_the_Public_ Interest_-_Ombudsperson.pdf

Pizarro Milian, R. (2016a). Modern campuses, local connections and unconventional symbols: Promotional practises in the Canadian community college sector. Tertiary Education \& Management, 22(3), 218-230.

Pizarro Milian, R. (2016b). Rethinking Stratification in PSE: Organizationally Maintained Inequality. McMaster University. Retrieved from https://macsphere. mcmaster.ca/bitstream/11375/19138/2/Pizarro Milian, Roger - Dissertation Final Version.pdf

Pizarro Milian, R. (2017). What's For Sale At Canadian Universities? A Mixed-Methods Analysis of Promotional Strategies. Higher Education Quarterly, 71(1), 53-74.

Pizarro Milian, R. (2017). "Forging appealing identities in complex environments: a case study of American law schools." Tertiary Education and Management, 1-15 (available ahead of print).

Pizarro Milian, R., \& Davidson, C. (2017). Symbolic resources and marketing strategies in Ontario higher education: a comparative analysis. Journal of Further and Higher Education, 42(2), 143-157.. http://doi.org/10.1080/0309877X.2016.1206859

Pizarro Milian, R., Davies, S., \& Zarifa, D. (2016). Barriers to Differentiation: Applying Organization Studies to Ontario Higher Education. Canadian Journal of Higher Education, 46(1), 19-37.

Pizarro Milian, R., \& Hicks, M. (2014). Ontario private career colleges: an exploratory analysis. Toronto, ON: Higher Education Quality Council fo Ontario.

Pizarro Milian, R., \& McLaughlin, N. (2017). Canadian Sociology for Sale? Academic Branding in a Neo-Liberal Age. The American Sociologist, 48(2), 171-191. http://doi. org/10.1007/s12108-016-9318-9

Pizarro Milian, R., \& Quirke, L. (2017). Alternative pathways to legitimacy: promotional practices in the Ontario for-profit college sector. Journal of Marketing for Higher Education, 27(1), 77-98.

Pizarro Milian, R., \& Quirke, L. (2017). Crafting legitimate identities: Promotional strategies in the Ontario non-elite private school sector. Educational Studies, 53(4), 342358 . 
Powell, W. W., \& Colyvas, J. (2008). Microfoundations of institutional theory. In R. Greenwood, C. Oliver, R. Suddaby, \& K. Shahlin-Anderson (Eds.), The Sage Handbook of Organizational Institutionalism (pp. 276-298). Thousand Oaks, CA: Sage.

Powell, W.W., Horvath, A. and Brandtner, C. (2016). Click and mortar: Organizations on the web. Research in Organizational Behavior, 36, 101-120.

Quirke, L. (2006). “ Keeping Young Minds Sharp ”: Children 's Cognitive Stimulation and the Rise of Parenting Magazines , 1959-2003. Canadian Review of Sociology \& Anthropology, 43(4), 387-406.

Quirke, L. (2009). Legitimacy through alternate means: schools without professionals in the private sector. British Journal of Sociology of Education, 3o(5), 621-634. http:// doi.org/10.1080/01425690903115809

Quirke, L. (2013). Rogue Resistance: Sidestepping Isomorphic Pressures in a Patchy Institutional Field. Organization Studies, 34(11), 1675-1699. http://doi. org/10.1177/0170840613483815

Quirke, L. (2016). Fat-proof your child": Parenting advice and "child obesity. Fat Studies, 5(2), 137-155.

R.A. Malatest \& Associates. (2007). Survey of Canadian Career College Students: Phase I. Edmonton, AB. Retrieved from http://www.cirst.uqam.ca/Portals/o/docs/ FondationBM/080331_Phase_I_Institutional_Survey_EN.pdf.pdf

R.A. Malatest \& Associates. (2008). Survey of Canadian Career College Students: Phase II. Edmonton, AB. Retrieved from http://www.cirst.uqam.ca/Portals/o/docs/ FondationBM/080331_SCPEP_EN.pdf

R.A. Malatest \& Associates. (2009). Survey of Canadian Career College Students: Phase III. Edmonton, AB. Retrieved from https://library.carleton.ca/sites/default/files/ find/data/surveys/pdf_files/millennium_rs-42_2009-03-26_en.pdf

Riff, D., Lacy, S., \& Fico, F. (2014). Analyzing media messages: Using quantitative content analysis in research. New York and London: Routledge.

Rushowy, K. (2015). Ontario to provide $\$ 7.6 \mathrm{M}$ to help former Everest College students. Retrieved December 8, 2016, from https://www.thestar.com/news/gta/2015/o3/11/ ontario-to-provide-76m-to-help-former-everest-college-students.html

Saichaie, K., \& Morphew, C. C. (2014). What College and University Websites Reveal About the Purposes of Higher Education. Journal of Higher Education, 85(4), 499-530. http://doi.org/10.1353/jhe.2014.0024

Sauder, M., \& Espeland, W. N. (2009). The discipline of rankings: Tight coupling and organizational change. American Sociological Review, 74(1), 63-82.

Scott, R. W. (2010). Higher Education in America: An Institutional Field Approach. In Reform and Innovation in the Changing Ecology of U.S. Higher Education: Inaugural Strategy Session. Stanford, CA.

Selznick, P. (1996). Institutionalism "Old" and "New." Administrative Science Quarterly, 41(2), 270. http://doi.org/10.2307/2393719 
Sink, A. \& Mastro, D. (2017). Depictions of gender on primetime television: A quantitative content analysis. Mass Communication and Society 20(1), 3-22.

Statistics Canada. (2016). Postsecondary enrolments by institution type, registration status, province and sex (Both sexes). Retrieved December 8, 2016, from http://www. statcan.gc.ca/tables-tableaux/sum-som/lo1/csto1/educ71a-eng.htm

Stemler, S. (2001). An overview of content analysis. Practical Assessment, Research \& Evaluation, 7(17), 1-10.

Stevens, M. L. (2015). The Changing Ecolgoy of U.S. Higher Education. In M. Kirst \& M. L. Stevens (Eds.), Remaking College: The Changing Ecology of Higher Education (pp. 1-18). Stanford, CA: Stanford University Press.

Stevens, M. L., Armstrong, E. a., \& Arum, R. (2008). Sieve, Incubator, Temple, Hub: Empirical and Theoretical Advances in the Sociology of Higher Education. Annual Review of Sociology, 34(1), 127-151. http://doi.org/10.1146/annurev.soc.34.040507.134737

Stuckey, J., \& Munro, D. (2013). The need to make skills work: the cost of Ontario's skills gap. Ottawa, ON: Conference Board of Canada.

Suddaby, R. (2006). From the editors: What grounded theory is not. Academy of Management Journal, 49(4), 633-642.

Sweet, R. (1993). A profile of private vocational training schools. Canadian Journal of Higher Education, 23(3), 36-63.

Tobolowsky, B. F., \& Lowery, J. W. (2014). Selling college: a longitudinal study of American college football bowl game public service announcements. Journal of Marketing for Higher Education2, 24(1), 75-98.

Toma, D. (2009). Positioning for prestige in American higher education: Case studies of strategies at four public institutions toward "getting to the next level." Los Angeles, CA. Retrieved from https://cerpp.usc.edu/wp-content/blogs.dir/236/files/2013/10/ CERPPSummaryPaperToma.doc

Toor, A. (2015). Access to private career colleges: an investigation into students' decision to apply for admission. Memorial University of Newfoundland. Retrieved from http://research.library.mun.ca/9682/1/thesis.pdf

Trow, M. (1996). Trust, markets and accountability in higher education: A comparative perspective. Higher Education Policy, 9(4), 309-324. http://doi.org/10.1016/So9528733(96)00029-3

U.S. Government Accountability Office. (2010). FOR-PROFIT COLLEGES Undercover Testing Finds Colleges Encouraged Fraud and Engaged in Deceptive and Questionable Marketing Practices. Washington, DC. Retrieved from http://www.gao. gov/assets/130/125197.pdf

Will, E. M., \& Callison, C. (2006). Web presence of universities: Is higher education sending the right message online? Public Relations Review, 32(2), 180-183. http://doi. org/10.1016/j.pubrev.2006.02.014 
Winter, S. J., Saunders, C., \& Hart, P. (2003). Electronic window dressing: impression management with Websites. European Journal of Information Systems, 12(May), 309322.

Zlomislic, D. (2009). College sold fake diplomas. Retrieved December 8, 2016, from https://www.thestar.com/news/investigations/2009/09/17/college_sold_fake_ diplomas.html

\section{Contact Information}

Roger Pizarro Milian

Centre for the Study of Canadian and International Higher Education

University of Toronto

rogerpizarro.milian@utoronto.ca

Roger Pizarro Milian is a Visiting Researcher at the Centre for the Study of Canadian and International Higher Education (CIHE). His research interests are in the sociology of education, organization studies, and social stratification.

\section{Appendix}

FPCs by Province

\begin{tabular}{|c|c|c|c|c|c|c|c|}
\hline \multirow[t]{2}{*}{ Province } & \multirow{2}{*}{$\begin{array}{l}\text { CICIC } \\
\text { Profiles }\end{array}$} & \multirow{2}{*}{$\begin{array}{c}\text { URLs } \\
\text { Extracted }\end{array}$} & \multirow{2}{*}{$\begin{array}{l}\text { Unique } \\
\text { URLs }\end{array}$} & \multicolumn{2}{|c|}{ Unresponsive } & \multirow{2}{*}{$\begin{array}{c}\text { Total } \\
\text { Examined }\end{array}$} & \multirow{2}{*}{$\begin{array}{c}\% \text { of } \\
\text { Unique URLs }\end{array}$} \\
\hline & & & & Down & Scripts & & \\
\hline Alberta & 160 & 140 & 96 & 4 & 10 & 82 & $85.4 \%$ \\
\hline $\begin{array}{l}\text { British } \\
\text { Columbia }\end{array}$ & 349 & 337 & 323 & 11 & 39 & 273 & $84.5 \%$ \\
\hline Manitoba & 58 & 35 & 27 & 1 & 2 & 24 & $88.9 \%$ \\
\hline New Brunswick & 47 & 36 & 35 & 3 & 8 & 24 & $68.6 \%$ \\
\hline Newfoundland & 23 & 22 & 15 & 1 & 3 & 11 & $73.3 \%$ \\
\hline $\begin{array}{l}\text { Northwest } \\
\text { Territories }\end{array}$ & 1 & 1 & 1 & $\mathrm{O}$ & $\mathrm{O}$ & 1 & $100 \%$ \\
\hline Nova Scotia & 43 & 42 & 38 & 2 & 8 & 28 & $73.7 \%$ \\
\hline Ontario & 574 & 522 & 341 & 14 & 50 & 277 & $81.2 \%$ \\
\hline $\begin{array}{l}\text { Prince Edward } \\
\text { Island }\end{array}$ & 15 & 12 & 9 & 1 & 1 & 7 & $77.8 \%$ \\
\hline Saskatchewan & 38 & 32 & 29 & 2 & 3 & 24 & $82.8 \%$ \\
\hline Total & 1,308 & $\mathbf{1 , 1 7 9}$ & 914 & 39 & 124 & 751 & 82.2\% \\
\hline
\end{tabular}

